\title{
FANUC M-1iA 0.5A válogató robot karbantartása, üzembe helyezése és iRVision alapú képfelismerés megvalósítása
}

\author{
Korsoveczki Gyula \\ Mechatronikai Tanszék \\ Debreceni Egyetem, Müszaki Kar \\ Debrecen, Magyarország \\ korsoveczki.gyula@gmail.com
}

\author{
Erdei Timotei István \\ Mechatronikai Tanszék \\ Debreceni Egyetem, Müszaki Kar \\ Debrecen, Magyarország \\ timoteierdei@eng.unideb.hu
}

\author{
Dr. habil. Husi Géza \\ Mechatronikai Tanszék \\ Debreceni Egyetem, Müszaki Kar \\ Debrecen, Magyarország \\ husigeza@eng.unideb.hu
}

\begin{abstract}
Absztrakt - A feladatmegvalósítás során a Debreceni Egyetem Műszaki Karán található FANUC M-1iA 0.5A típusú, delta-tripod kialakítású válogató robot karbantartása és üzembe helyezése valósult meg, továbbá a robothoz egy iRVision rendszer alapú képfelismerő eljárás készült. Ennek eredményeként az eljáráshoz társított program futtatásával a robot képessé vált képfelismerésen alapuló munkavégzésre.
\end{abstract}

Kulcsszavak - FANUC; M-1iA 0.5A; delta-tripod; robot; iRVision; képfelismerés

\section{BEVEZETŐ}

$\mathrm{Az}$ Épületmechatronikai Kutatóközpontban innovatív rendszerek kialakítására helyezzük a hangsúlyt, képelemzési technológia felhasználásával, melyek elöremutató irányzatot képviselnek [10][11].

A rendszerek kialakításánál a Fuzzy rendszerek szolgáltatnak támpontot [12].

A robotok térhódítása egyre számottevőbb az ipar minden területén. A technika fejlődésével és az igények növekedésével szükség van automatizált gyártósorokra, melyek gyorsaságát és pontosságát ipari robotok biztosítják.

A feladatmegvalósítás alkalmával egy ilyen ipari robottal szerettem volna foglalkozni, így esett a választásom a Debreceni Egyetem Müszaki Karán található FANUC M-1iA $0.5 \mathrm{~A}$ típusú delta-tripod kialakítású válogató robotra [13][14].

A karbantartási munkálatok elvégzését követően bemértem a robot által későbbiekben használt szerszámot, kialakítottam és optimalizáltam a robot munkaterét, majd bemértem a feladat során használt munkaterületet. Ezt követően pedig elláttam a robotot további megfogó szerszámok, illetve tartószerkezeti stabilizáló elemek terveivel, amik a mellékelt CD lemezen megtalálhatóak. Célként tűztem ki továbbá a FANUC iRVision rendszerének megismerését és működésének elsajátítását, végezetül pedig egy képfelismerő eljárás létrehozását, alkalmazását és annak bemutatását. Ezek eredményeként pedig a robot müködése hatékonyabb lett, feladatköre bővült, illetve alkalmassá vált oktatási célra is.

\section{A RENDSZER MÜSZAKI ÁTTEKINTÉSE}

\section{A. FANUC M-1iA 0.5A robot}

A feladatmegvalósítás során használt robot egy 6 szabadságfokkal rendelkező, delta-tripod kialakítású robot. Mozgékony, kiváló munkatempóra képes, illetve bármilyen szögben tud dolgozni. Alkalmas válogatási feladatok és bonyolult részegység-összeszerelési munkálatok elvégzésére, ahol fontos a magas szintü ismétlési pontosság [1].

Alkalmazási területei az elektronika, élelmiszeripar, orvosi műszerek gyártása, optikai-ipar, gyógyszeripar és a finommechanika [1].

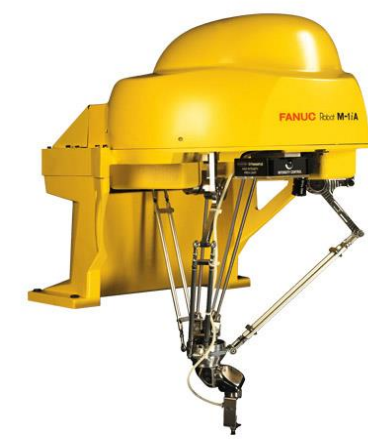

1. ábra: FANUC M-1iA 0.5A robot [1]

A robot technikai specifikációi:

- A robot tengelyeinek száma: 6

- Maximális kinyúlása: $280 \mathrm{~mm}$

- Ismétlési pontossága: +/- 0,02 mm

- Mechanikai tömege: $23 \mathrm{~kg}$

- Teherbírása: 0,5 kg (hasznos tömeg)

- Maximális sebessége: 4000 mm/s [1] 


\section{B. FANUC R-30iB Mate vezérlöegység}

A robot vezérléséért a FANUC R-30iB Mate típusú OpenAir vezérlőszekrény felel. Kompakt, így könnyen integrálható termelési cellákba, illetve a robot számára kialakított állványba. Nem Windows operációs rendszer fut rajta, hanem egy speciális, FANUC által fejlesztett rendszer, így stabilabb, illetve védett a számítógépes hackertámadásokkal szemben. Előnye továbbá, hogy nem szükséges keretrendszer a vezérlő szoftver futtatásához [2].

Az ipari környezet igényeinek is eleget tesz, hiszen megfelelö védelemmel rendelkezik a nedvesség és a por ellen. $\mathrm{Az}$ iRVision rendszer könnyebb használata érdekében Ethernet port is található rajta. Főbb részei egy kétállású kapcsoló, mely a vezérlőegység bekapcsolásáért felelös, egy biztonsági célt szolgáló piros színü vészleállító gomb, egy kulccsal müködtethető üzemmód váltó és egy ciklusprogram futásáért és megszakításáért felelős zöld nyomógomb [2].

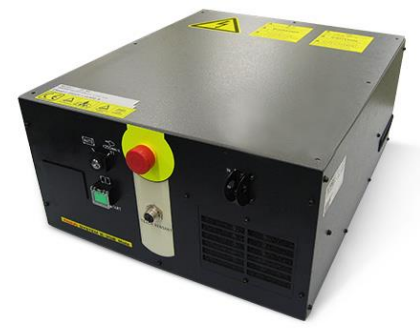

2. ábra: FANUC R-30iB Mate vezérlőegység [3]

\section{FANUC iPendant Touch}

A robotot kétféle módon lehet programozni. Az egyik a Karel programozási nyelv használata, melyhez egy különálló számítógép szükséges, a másik pedig a FANUC által készített kézi kontroller, amely az iPendant Touch nevet viseli. Mivel az utóbbi megoldás blokk stílusú nyelvet alkalmaz, ezáltal a robot programozása gyorsabb és több lehetőség áll rendelkezésre.

Az iPendant Touch ergonomikus kialakítással rendelkezik, érintőképernyős, programozói környezete pedig felhasználóbarát. További bővítésekhez funkciógombokat tartalmaz, továbbá egyszerre két ablak is megjeleníthető a nagyméretü színes kijelzőjén. Tartalmaz emellett 4D-s tervező funkciót, illetve USB bemenetet külső tárhely vagy egér csatlakoztatására [4]. Főbb részei a nagyméretü színes kijelző, a billentyüzet, a háromállású biztonsági Deadman kapcsoló, a szintén biztonsági célt szolgáló vészleállító gomb, illetve a kétállású iPendant engedélyező kapcsoló.

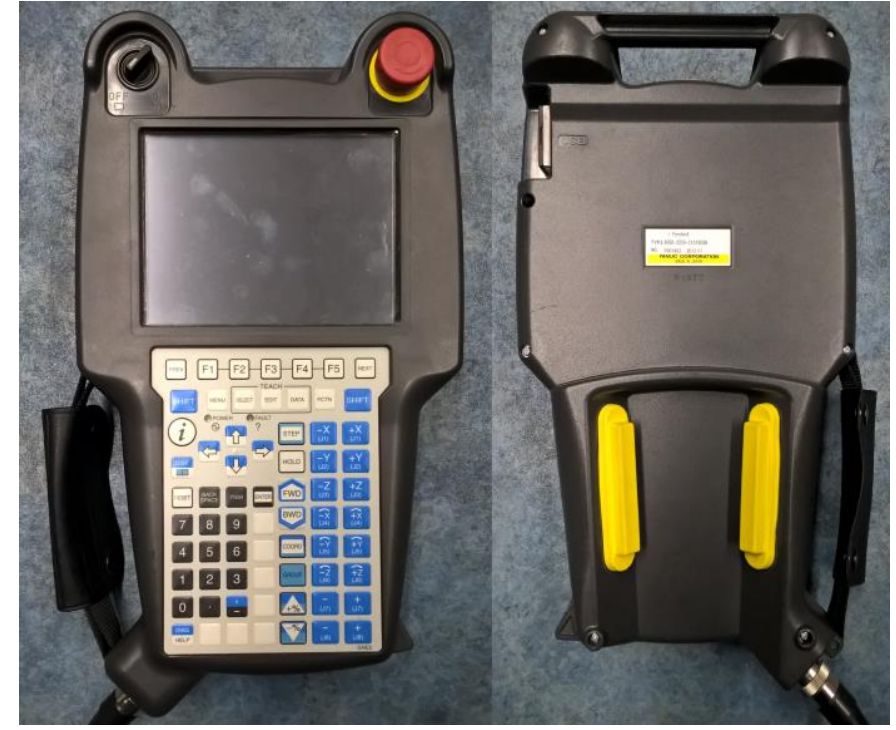

3. ábra: FANUC iPendant Touch

\section{SONY XC-56 típusú kamera}

A rendszer tartalmaz továbbá egy SONY által gyártott monokróm ipari kamerát, amely az iRVision alapú képfelismerő rendszerrel kompatibilis. A kamera hivatott elvégezni a projekt során megvalósított képfelismeréshez társított program vizuális részét.

Főbb technikai adatai:

- Maximális felbontása: VGA felbontás (648 x 494)

- Képfrissítés: 120 képkocka / másodperc

- Minimális fényszükséglete: 0,5 lux

- Magas ütés és rezgés elleni védelem [5]

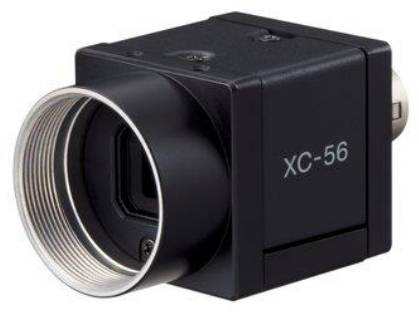

4. ábra: SONY XC-56 típusú kamera [5]

\section{KARBANTARTÁSI MUNKÁLATOK ELVÉGZÉSE}

A. A jeladó elemcseréje

A feladatmegvalósítás során első feladatom az jeladó (Pulsecoder) elemeinek lemerüléséből adódó hibák kiküszöbölése volt. A robot 6 darab mozgatható axisát 6 darab váltóáramú szervomotor hajtja meg, melyek pontosságáért és pontos pozícionálásért optikai elven müködö inkrementális forgójeladó a felelős. Ennek a típusú jeladónak a legnagyobb hátránya, hogy folyamatos tápellátás szükséges neki, különben a számlálás eredménye elvész [6]. Ezt akadályozza meg 4db Industrial ALCALINE típusú elem, melyek szolgáltatják a 
folyamatos tápellátást. Azonban a robot utolsó használata óta eltelt idő alatt ezek az elemek lemerültek, így a robot mozgásképtelen állapotba került.

Ebben az esetben a robot egy bizonyos SRVO-062 BZAL alarm (Group: $i$ Axis: $j$ ), más néven Battery Zero Alarm hibajelzést ad. Az újbóli működéshez azonban nem elég elvégezni az elemcserét, szoftveresen is törölni kell a hibaüzenetet. Ehhez az iPendant Touch segítségével be kell lépni a robot menüjébe, amely a MENU gomb megnyomásával történik. Ezt követően a NEXT (0-s) gomb segítségével a következő oldalra kell lapozni, majd ott a SYSTEM (6-os) opciót kell kiválasztani a számbillentyük használatával. Ezen belül a VARIABLES (2-es) lehetőség megnyitása után érhető el a robotban tárolt változók és értékek könyvtára. Megkönnyíti a keresését az ITEM gomb használata, amelynek segítségével megadható a keresett érték sorszáma. Jelen esetben a 308-as sorszámú, \$MRC elnevezésü változót kell megkeresni, majd ott kiválasztani a 14-es sorszámú \$SPC_RESET változót, ami a SERIAL PULSECODER RESET rövidítése. A változó FALSE értékének F4 gombbal történő TRUE értékre állítása után szükséges az iPendant Touch hátoldalán lévő Deadman háromállású kapcsoló középső állásba húzása és ezzel egyidejüleg a RESET billentyü megnyomása a feladat befejezéséhez. Ezt követően a robot feszültségmentesítése, majd újból bekapcsolása után újból mozgathatóak az axisok. $\mathrm{Az}$ itt leírt müveletek végrehajtása után sikerült elérni, hogy a robot axisait JOINT koordináta rendszerben mozgatni lehessen [7].

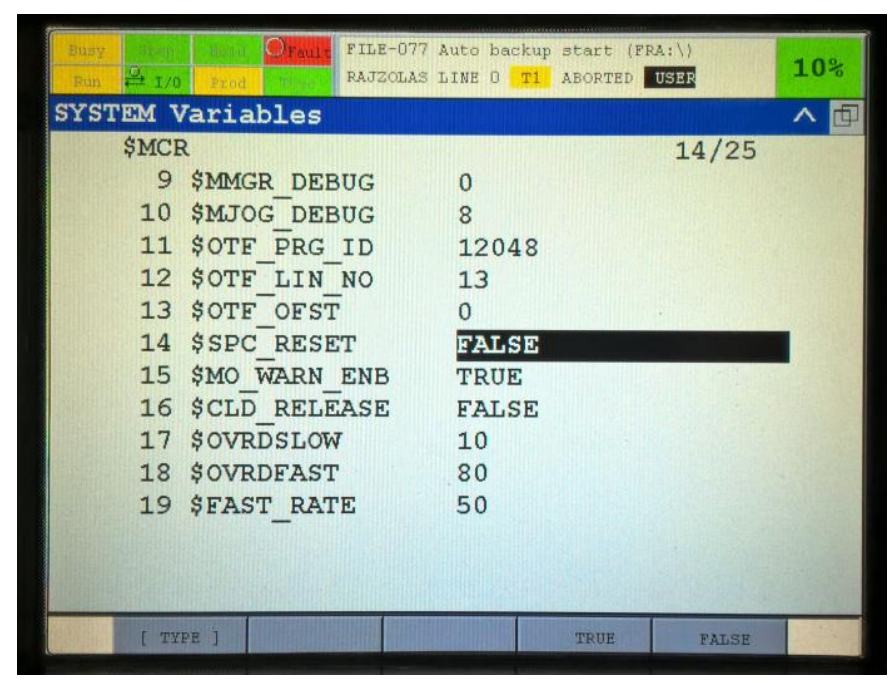

5. ábra: A \$SPC_RESET folyamata

\section{B. A MASTER müvelet és a kalibrálás végrehajtása}

A jeladó elemcseréje, illetve az azt követő szoftveres karbantartást követően a roboton végre kellett hajtani egy MASTER müveletet, illetve egy kalibrálást. A robot aktuális pozíciója az egyes tengelyekhez tartozó impulzusértékek alapján határozható meg. A MASTER tehát egy olyan müvelet, melynek során az egyes robot axisok tengely szögeit a hozzájuk tartozó jeladó értékéhez társítjuk, így a zéró helyzethez jeladó értékeket tudunk hozzárendelni. A müveletet gyárilag szokták végrehajtani, így mindennapos elvégzése szükségtelen. Azonban mindenképpen szükséges motorcsere után, impulzusadó cseréje után, kábelcsere után, illetve az impulzusadó elemeinek lemerülését követően [8].

A feladatmegvalósítás során a roboton QUICK MASTER müveletet hajtottam végre. Ez a lehetőség egy a felhasználó által megadott pozícióban történik. Lényege, hogy egy adott motor egy adott forgáspozíciójához egy megfelelö impulzusérték kapcsolódik egy forgáson belül, mivel egy forgószög abszolút értéke egy forgatás alatt nem vész el. A művelet alkalmazható elemlemerülés miatti értékvesztés esetén, viszont nem használható, jeladó cserét követően [8].

A QUICK MASTER müvelet megvalósításához az iPendant Touch menüjéből a korábban ismertetett módon meg kell nyitni a SYSTEM opciót, ahol a 3-as gomb megnyomásával kiválaszthatjuk a MASTER/CAL lehetőséget. Innen elérhetővé válik az összes MASTER müvelet [8]. Elöször azonban a robot axisait valamely irányba el kell mozdítani. Ehhez a COORD gomb segítségével JOINT koordináta rendszerbe váltjuk a robotot. Ezt követi a Deadman kapcsoló középső állásba húzása, ezzel egyidejűleg a RESET gomb megnyomása, ami feloldja a FAULT hibajelzést, majd a Dedman kapcsoló, a SHIFT gomb és az iPendant jobb oldalán található iránygombok valamelyikének együttes megnyomására a robot szerszámközéppontja a választott irány mentén mozdul el.

A lehetséges irányok a következők:

- $\quad+X ;-X ;+Y ;-Y ;+Z ;-Z$ : A Descartes-féle koordináta rendszer tengelyei mentén történő mozgás.

- $\quad+X \overrightarrow{;}-X \overrightarrow{;}+Y \overrightarrow{;}-Y \overrightarrow{;}+Z \overrightarrow{;}-Z \overrightarrow{:}$ A Descartes-féle koordináta rendszer tengelyei körüli elfordulás.

A mozgatás végeztével a QUICK MASTER kiválasztásához a navigációs gombok segítségével odanavigálunk, majd az ENTER gomb megnyomásával kiválasztjuk és végrehajtjuk a müveletet.

A müveletek végrehajtása után értéket kap a jeladó, azonban ennek véglegesítéséhez, kalibrálni kell a robotot. A kalibráció alkalmával elmentjük a QUICK MASTER müveletek során bevitt impulzus értékeket. A kalibrálás lehetősége ugyanabból az ablakból elérhető, mint a MASTER. A müvelet elvégzése a CALIBRATE opció kiválasztásával lehetséges [8]. 


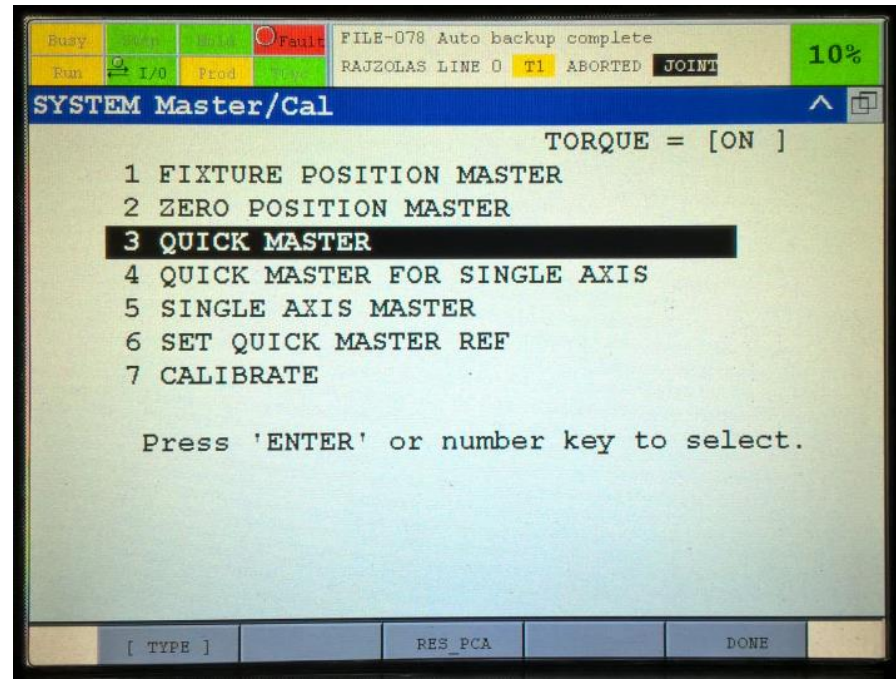

6. ábra: A MASTER/CAL menü

A feladatom során végrehajtottam a fent leírt müveletek mindegyikét, aminek köszönhetően sikerült a robotot mozgásba hoznom, illetve elérni, hogy WORLD koordináta rendszerben is képes legyen dolgozni. A koordináta rendszer irányait szemléletes és figyelemfelkeltő ábrák segítségével feltüntettem, melyek elösegítik a robot gyorsabb és könnyebb programozását a későbbi felhasználók számára is.

\section{A ROBOT ÜZEMBE HELYEZÉSE}

\section{A. A szerszám bemérése}

A karbantartási munkálatok végeztével elkezdhettem beüzemelni és optimalizálni a robotot, melynek első lépése a későbbiekben használt szerszám bemérése volt.

A robot optimális és pontos müködéséhez elengedhetetlen a folyamat elvégzése. A szerszámbemérés alkalmával betanítjuk a robotnak a rajta lévő szerszám főbb geometriai méreteit, továbbá definiáljuk a szerszámközéppontot, más néven a TOOL CENTER POINT-ot (TCP).

A szerszámbemérés megvalósításához szükséges belépni az iPendant Touch menüjébe a már ismertetett módszer segítségével. A menübe érkezve a SETUP (6-os) opciót kell kiválasztani. A opción belül a 3-as gombbal tudjuk elérni a szerszámbemérés felületét, a FRAMES lehetőséggel. Itt az [OTHER] funkciót megnyitva kiválasztható, a szerszámbemérés, a TOOL FRAME. Ezt követően a rendszer listázza nekünk a már bemért szerszámokat. Lehetőség van már meglévő szerszám módosítására, vagy teljesen új szerszám bemérésére. Ez utóbbihoz egy üres mezőre kell irányítani a kurzort, majd a CREATE paranccsal elkezdeni a létrehozást. A [METHOD] funkció megnyitásával kiválasztható a szerszámbemérés módszere. A rendszer 4 lehetőséget kínál fel, nevezetesen Three Point, Six Point, Two Point $+Z$ és Direct Entry módszereket.

A feladatmegvalósítás során használt $3 \mathrm{D}$ nyomtatott szerszám a Three Point módszerrel lett bemérve, melynek lényege, hogy a célszerszámmal egy választott objektumot három különböző irányból és orientációval érintünk meg ugyanazon a ponton. A módszer kiválasztását követően a rendszer számára 3 pontot kell megadni APPROACH POINT 1, 2 és 3 néven. Ehhez a TCP-t a már ismertetett módon a választott referencia pontra kell irányítani 3 különböző irányból és orientációval, majd a pontokat egyesével elmenteni a SHIFT gomb nyomva tartásával és a RECORD parancs egyidejü kiválasztásával. Lehetőségünk van továbbá a COMMENT mező segítségével megjegyzést hozzáfüzni a bemért szerszámhoz.

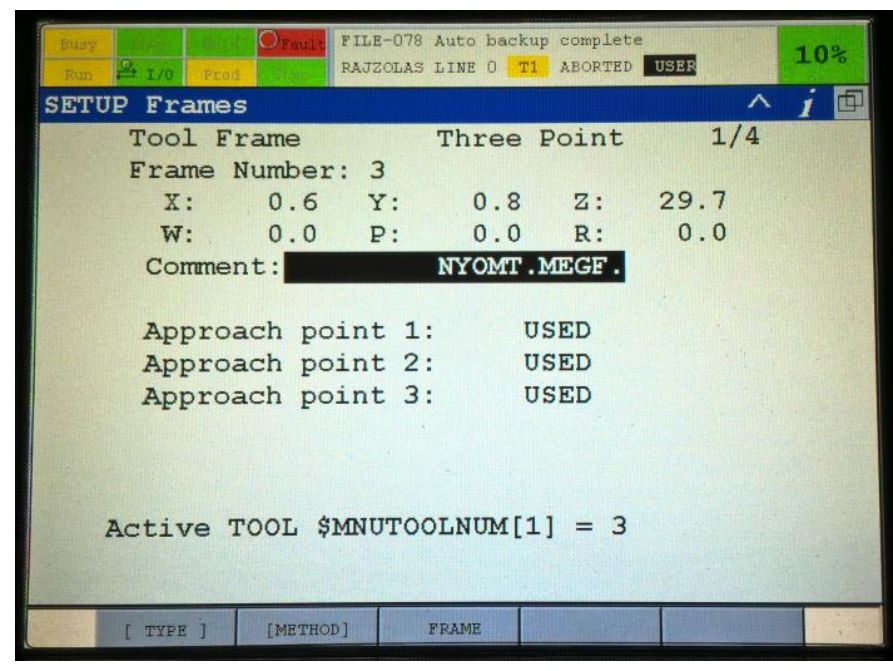

7. ábra: A szerszám bemérése felülete

\section{B. A munkaterület optimalizálása}

Feladataim következő céljaként a robot munkaterületének optimalizálását tüztem ki, melynek köszönhetően a robot feladatköre bővült, továbbá munkaterületének megfelelő beállításával a hatékonysága is nőtt.

A munkálatok megkezdése előtt a robot rendelkezett már egy számára kialakított munkaterülettel, a jelenlegi feladatmegoldás szempontjából azonban ez alkalmatlannak minősült a további használatra.

Első problémaként merült fel, hogy a munkaasztala nem vízszintes, hanem ahhoz képest egy körülbelül 20 fokos lehajlással rendelkezett. Ez alkalmatlanná tette a robotot a 2Ds feladatok ellátásra, és mivel a későbbi programmegvalósítás során 2D-s képfelismerő eljárást használtam, így ezt a hibát le kellett küzdeni. A megoldást egy perforált alumínium rudakból készült állvány jelentette, mely kompatibilisnek bizonyult a szintén perforált alumíniumból készült robot tartószerkezettel. A rögzítés a lemezek sínjeibe illeszthető, csavarmenettel rendelkező fém elemekkel történt, melyek a sín mentén elmozdíthatóak. Ezáltal, a csavarkötést szorításával fixen tartanak, lazításával pedig a tartószerkezet a sín mentén elmozdítható, vagyis a tartószerkezet állítható.

Munkaasztalként egy KUKA által gyártott, fém gyakorlóasztalt szereltem fel, mely stabil, felszínén speciálisan kialakított függöleges szintkülönbségek vannak, továbbá a rajta lévő alakzatok kiválóan használhatók gyakorlási célra. Problémaként merült fel viszont, hogy a tartószerkezetre 
rászerelve a robot maximális $280 \mathrm{~mm}$ hosszúságú kinyúlása nem elegendő a gyakorlópad felszínének megérintésére. Így szükségessé vált a pad megemelése, viszont fontos kritériumként fogalmaztam meg a stabilitás megtartását és az állíthatóságot. A feladatot 4 darab M6-os átmérőjü, $120 \mathrm{~mm}$ hosszúságú menetes csavarral oldottam meg. A csavarok kompatibilisek a sínbe illeszthető fém elemekkel, így egy WORLD koordináta-rendszer szerinti $X$ és $Y$ irányú állíthatóságot biztosítanak. A gyakorlópad rögzítése céljából rendre csavaranyákat és lapos alátéteket alkalmaztam, így a gyakorlópad pozíciója függőlegesen változtatható, vagyis állítható a $\mathrm{Z}$ pozíció.

A megvalósított változásoknak köszönhetően a robot munkaterét optimálisra be tudtam állítani. A 8 . ábrán jelöltem az állíthatósági irányokat.

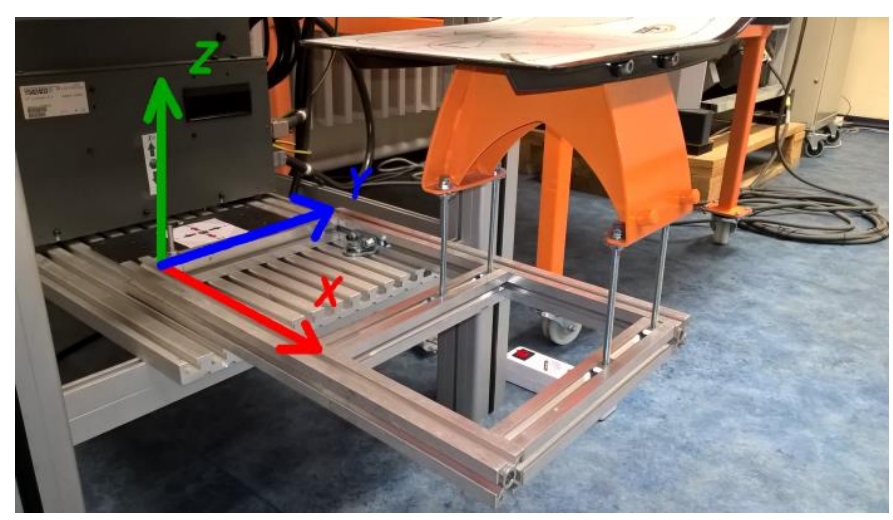

8. ábra: A munkaterület új kialakítása

\section{A munkaterület bemérése}

A munkatér megfelelő kialakítását követően lehetőség nyílt a robot által későbbiekben használt munkaterület bemérésére, a koordináta rendszer felvételére és az irányok megadására.

A munkaterület bemérése az iPendant Touch menüjének SETUP (6-os) opciójában érhető el éppúgy, mint a szerszámbemérés. Ehhez meg kell nyitni a FRAMES (3-as) lehetőséget, majd az [OTHER] fület lenyitva az USER FRAME kiválasztásával lehet bemérni a kívánt munkaterületet. Itt is módosíthatunk már meglévő munkaterület és mérhetünk be újat. A [METHOD] opció a Three Point, a Four Point és a Direct Entry módszereket kínálja fel.

A feladatmegoldás során a Three Point módszert alkalmaztam, mely esetében meg kell adni a munkaterület origóját, illetve egy-egy pontot $X$ és $Y$ irányokban. A bemért irányok megegyeznek a WORLD koordináta rendszer irányaival.

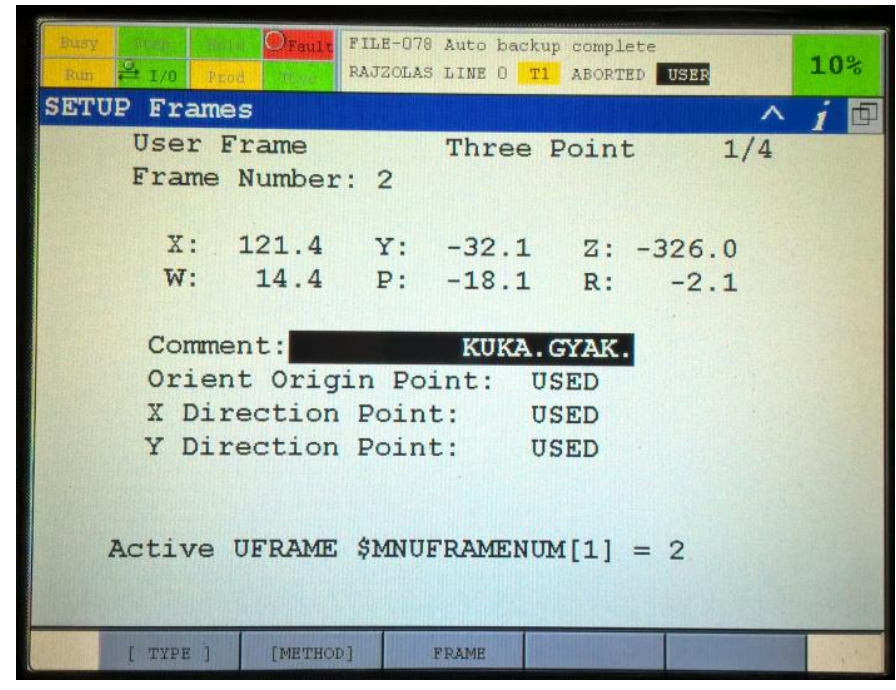

9. ábra: A munkaterület bemérése

\section{IRVISION KÉPFELISMERŐ ELJÁRÁS LÉTREHOZÁSA}

Az iRVision nem más, mint a FANUC speciális PLUG \& PLAY vizuális érzékelőrendszere. A robot egy kamerával és az ahhoz kapcsolódó feldolgozórendszerrel rendelkezik, amely látást ad a robotnak. Kialakítását tekintve az R-30iB Mate érzékelöbe teljes mértékben integrálva van, így könnyen használható és magas fokú rugalmasságot kínál a felhasználóknak. Az iRVision rendszernek köszönhetően a robot alkalmas válogatási, vonalkövetési, összeszerelési feladatok ellátására, mivel 2D-ben és 3D-ben is képes tetszőleges méretü, alakú, színű és helyzetü munkadarabokat felismerni [9].

A feladatmegvalósítás során az iRVision rendszer segítségével szerettem volna létrehozni egy olyan képfeldolgozó eljárást, melyet programmal összekapcsolva a robot felismer egy adott koordináta rendszert, majd annak origóját megérintve körberajzolja a koordináta-rendszerben elhelyezett, számára viszont nem látható háromszöget.

Az iRVision rendszer sajátosságai, hogy közvetlen csatlakozása van a vezérlö processzorához, számítógépes csatlakozás esetén pedig Ethernet kábel és egy Microsoft Internet Explorert futtató PC szükséges.

A megvalósítás első lépéseként az Ethernet kábel segítségével csatlakoztatni kell a számítógépet a robot vezérlőjéhez. A kommunikációhoz a PC IPv4 címének átírása szükséges 192.168.0.11-es címre. Ezt követően az Internet Explorert megnyitva a 192.168.0.1 címről érhetjük el a vezérlő szoftverét. A rendszer müködéséhez nélkülözhetetlen Microsoft Internet Explorer kiegészítö az iRVision Setup menüre kattintva tölthető le.

A megjelenő menüből elsőként a [TYPE] opcióból a CAMERA SETUP TOOLS lehetőséget kell választani, majd a CREATE opció segítségével egy újat létrehozni. Itt definiáljuk az alkalmazott kamerát, kiválasztjuk a fix kamera opciót és beállítjuk az expozíciós időt. 
Következő lépésként a kamera kalibrációját kell elvégezni a CAMERA CALIBRATION TOOLS opcióban. Ehhez azonban elengedhetetlenek a FANUC által gyártott kalibrációs rácsok, melyek segítségével a szoftver optimalizálni tudja a kamera beállításait a maximális hatásfok elérése érdekében. Jelen feladatok során a kalibrációs rácsok hiánya végett a kamera alapbeállításait használtam, mely egy meglévő és kiválasztható kalibrációs fájlként érhető el.

Mindezek után létre kell hozni egy új képfeldolgozó eljárást, ami egy VISION PROCESS TOOLS, azon belül pedig egy 2-D SINGLE - VIEW VISION PROCESS. Az általam készített képfeldolgozó eljárást „KRESHAROMSZOG” néven hoztam létre.

Ebben ki kell választani a kamera kalibrációját, az expozíciós módot és időt, továbbá a munkadarabok megtalálására vonatkozó egyéb kritériumokat. Meg kell adni továbbá a már bemért munkaterületet, illetve egy referenciapozíciót.

A menü tartalmaz egy GPM LOCATOR TOOL legörgethető lehetőséget, amit ha megnyitunk, betaníthatjuk a munkadarabot. A betanításhoz egy képet kell készíteni a munkadarabról a SNAP opció segítségével, majd a beépített eszközökkel kijelölni a betanítani kívánt munkadarabot, továbbá a keresés szempontjából lényegtelen részleteket „kimaszkolni” a TRAINING MASK paranccsal, ahogy ez a háromszöggel is történt.

Fontos eszközök a CONTRAST TRESHOLD, ami a szín szerinti keresést teszi lehetővé, az ORIENTATION opció, ami a keresett munkadarabok orientációjáért felelős, illetve a SCALE opció, aminek segítségével méret szerint is kereshetünk

A szerkesztés befejeztével és mentésével létrejön a képfeldolgozó eljárás, ami rögtön tesztelhető is. A tesztelés során a szoftver vizuálisan is jelzi is mutatja a keresés folyamatát, továbbá jelzi a talált munkadarabok számát és pontos pozícióját

A vázolt lépések végrehajtásával az eljárás sikeresen megvalósult, a koordináta-rendszer lett a robot betanított munkadarabja.

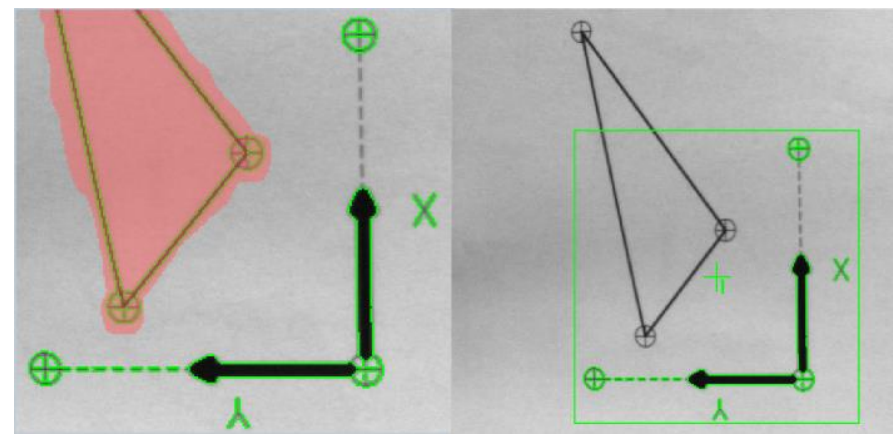

10. ábra: A munkadarab

\section{AZ ELJÁRÁSHOZ TÁRSÍTOTT PROGRAM ELKÉSZÍTÉSE}

\section{A. A programkód ismertetése}

A feladatmegvalósítás utolsó lépéseként egy olyan program megvalósítása volt a cél, amihez a képfelismerö eljárás társítható, így a robot gyakorlatban is tudja azt alkalmazni. A program futtatása során a robot képessé vált a munkaterében adott pozícióban, de tetszőleges helyen elhelyezett koordináta rendszer felismerésére és megérintésére is, amennyiben az elhelyezés a munkaterület $X$ és $Y$ irányaival párhuzamos, továbbá az abban lévő háromszög körberajzolására úgy, hogy annak a helye számára ismeretlen és csakis a koordináta-rendszertől függ.

A programozás az iPendant Touch segítségével történt, mely használata kényelmesebb és gyorsabb, mint a Karel programnyelvé.

Ennek értelmében elsőként a már bemért szerszámot és munkateret definiáltam az 1. és a 2. sorban.

A 3. lépésben létrehoztam egy pontot, melyben a TCP nem zavarja a kamera látóterét. A mozgás típusa lineáris (L), tehát egyenes vonalú, sebessége $100 \mathrm{~mm} / \mathrm{sec}$, a mozgás végén pedig megáll a robot (FINE).

A 4. parancssorban kapcsoltam össze a képfeldolgozó eljárást és a programot egy VISION RUN_FIND parancsopció segítségével. A keresés céljaként pedig a képfeldolgozó eljárás nevét adtam meg (KRESHAROMSZOG). A robot kamerája ekkor megvizsgálja a munkaterületet és kiértékeli az eljárás segítségével, hogy talál-e betanított munkadarabot.

Munkadarab találata esetén egy OFFSET változóba elmenti annak pozícióját az 5. sorral. Amennyiben nem talált, létrehoz egy ugrást (JMP) egy címzett fóliára (LBL [1]), ezzel átugorva a találathoz tartozó programrészt.

A 6-8. sorokban található parancsokkal a robot megérinti a felismert háromszög origóját, majd a következő parancsokkal a 9-14. sorokban P [4], P [5], P [6], P [7], P [5] és P [4] pontokkal körberajzolja a robot a háromszöget is.

A 15. parancssorban található az ugrási céllal létrehozott fólia, végezetül pedig a 16. és az [END] paranccsal a robot felveszi a P [1 : VIEW] pontot, majd befejezi a programfutást. 
1: $\quad$ UFRAME_NUM $=2$

2: UTOOL_NUM=3

$3: \mathrm{L} \quad \mathrm{P}[1: \mathrm{VIEW}] 100 \mathrm{~mm} / \mathrm{sec}$ FINE

4: VISION RUN_FIND 'KRESHAROMSZOG'

5. VISION GET_OFFSET

'KRESHAROMSZOG' VR [1] JMP LBL [1]

6: L P [2:APRCH $] 80 \mathrm{~mm} / \mathrm{sec}$ FINE

VOFFSET , VR [1]

$7: \mathrm{L} \quad \mathrm{P}[3: \mathrm{PICK}] 80 \mathrm{~mm} / \mathrm{sec}$ FINE

VOFFSET , VR [1]

$8: \mathrm{L} \quad \mathrm{P}[2: \mathrm{APRCH}] \quad 80 \mathrm{~mm} / \mathrm{sec}$ FINE

VOFFSET, VR [1]

9: L P [4] 100mm/sec FINE

VOFFSET , VR [1]

11. ábra: A programkód

\section{B. A folyamatábrás bemutatás}

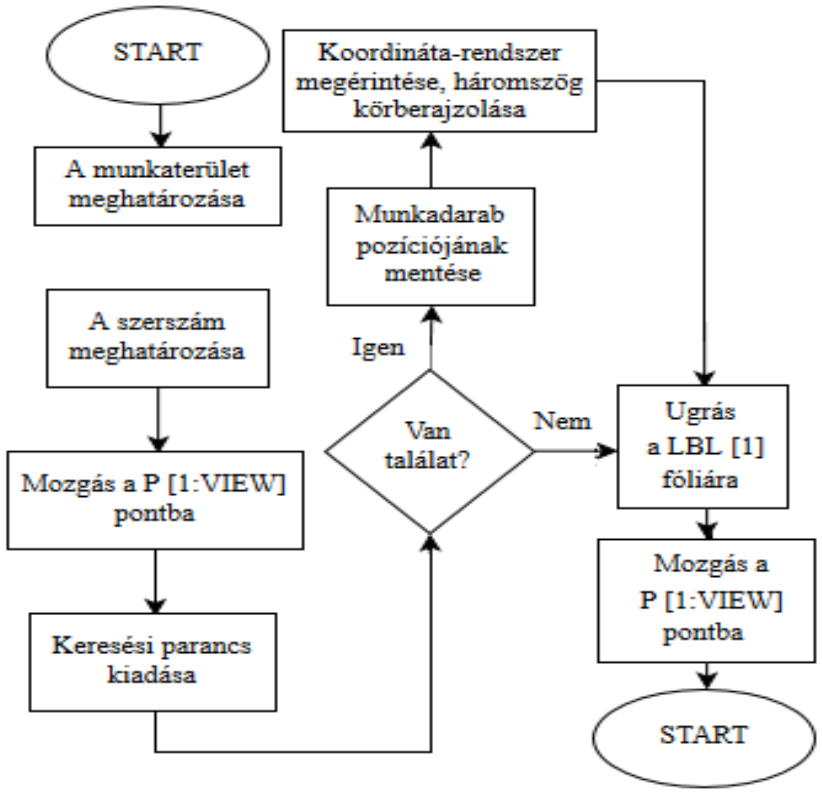

12. ábra: A folyamatábra

\section{VII. ÖSSZEFOGLALÁS}

A feladatmegvalósítás célja a robot karbantartása, a feladatorientált beüzemelése, továbbá iRVision rendszerének tesztelése, bemutatása volt az elkészült képfeldolgozó eljárás és a hozzá társított program segítségével. Az eredmény egy jól müködő rendszer lett, a kitüzött célok pedig megvalósultak. Szem előtt tartottam, hogy a robot alkalmassá váljon oktatási célokra és további tanszéki projektekre is, mint további megfogók tervezése, külső fényforrás telepítése és konvejor pálya létesítése. Mindezek mellett a kamera újrakalibrálása a kalibrációs rácsok alapján, nagymértékben megnövelné a robot pontosságát és bővítené a munkakörét. A szoftveres rész is problémamentesen kiegészíthető új programrészekkel és funkciókkal
A feladatmegoldás során ismereteim sokat bővültek az ipari robotokat illetően, melynek a későbbiekben bizonyára hasznát fogom venni.

\section{KÖSZÖNETNYILVÁNÍTÁS}

A publikáció elkészítését az EFOP-3.6.1-16-2016-00022 számú projekt támogatta. A projekt az Európai Unió támogatásával, az Európai Szociális Alap társfinanszírozásával valósult meg.

\section{HIVATKOZÁSOK}

[1] FANUC Hungary Kft., „M-1iA/0.5A,” [Online]. Available: http://www.fanuc.eu/hu/hu/robotok/robotsz\%c5\%b1r\%c5\%91-lap/m1sorozat/m-1ia-05a. [Hozzáférés dátuma: 27.11.2017.].

[2] FANUC Hungary Kft., „R-30iB vezérlő.” [Online]. Available: http://www.fanuc.eu/hu/hu/robotok/tartoz\%c3\%a9kok/r-30ibvez\%c3\%a9r1\%c5\%91. [ Hozzáférés dátuma: 27.11.2017.].

[3] RobotWorx, „FANUC R-30iB Open Air Cabinet,” [Online]. Available: https://www.robots.com/fanuc/controller/r-30ib-open-air-cabinet. [Hozzáférés dátuma: 27.11.2017.]

[4] FANUC Hungary Kft., „iPendant Touch,” [Online]. Available: http://www.fanuc.eu/hu/hu/robotok/tartoz\%c3\%a9kok/r-30ibvez\%c3\%a9r1\%c5\%91/ipendant-touch. [Hozzáférés dátuma: 27.11.2017.].

[5] SONY, "XC56," [Online] Available: https://pro.sony.com/bbsc/ssr/product-XC56/. [Hozzáférés dátuma: 27.11.2017.].

[6] Dr. Boza Pál, Dr. Pintér József, Gyártásautomatizálás, Győr, 2011.

[7] FANUC Robotics America, Inc., „M-1iA Operator Manual,” [Online]. Available: https://www.scribd.com/document/350205121/M-1iAOperator-Manual-B-83084EN-08. [Hozzáférés dátuma: 27.11.2017.].

[8] FANUC Robotics America, Inc., „R-30iA Mate CONTROLLER, [Online]. Available: http://www.msamc.org/aimss/documentation/pdf/manuals/lr_mate_man uals/R30iA\%20Mate\%20Controller.pdf. [Hozzáférés dátuma: 27.11.2017.].

[9] FANUC Hungary Kft., „Vizuális érzékelőrendszer,” [Online]. Available: http://www.fanuc.eu/hu/hu/robotok/tartoz\%c3\%a9kok/1\%c3\%a1t\%c3\%a 1s. [Hozzáférés dátuma: 27.11.2017.].

[10] G. Husi, P. T. Szemes, E. Dávid, T. I. Erdei, „Building Mechatronics Research Centre as energy aware Intelligent Space," Industrial Electronics Society, IECON 2013 - 39th Annual Conference of the IEEE; 01/2013.

[11] G. Husi, T. I. Erdei, Zs. Molnár, „A Novel Design of an Augmented Reality Based Navigation System \& its Industrial Applications," 15th IMEKO TC10 - Technical Diagnostics in Cyber-Physical Era Budapest, Hungary, 6 - 7 June, 2017 - Organised by: MTA SZTAKI - Hungarian Academy of Sciences - Institute for Computer Science and Control

[12] Baranyi Peter, Nagy Istvan, Korondi Peter, Hashimoto Hideki, „Genera guiding model for mobile robots and its complexity reduced neuro-fuzzy approximation," FUZZ-IEEE 2000: 9th IEEE International Conference on Fuzzy Systems. Konferencia helye, ideje: San Antonio, Amerikai Egyesült Államok, 2000.05.07-2000.05.10. (2) New York: IEEE, 2000. pp.1029-1032.

[13] Zs. Molnár, T. I. Erdei, A. Husam, G. Husi, „Self-developed CNC prototype as IoT device," FMTÜ - XXII. International Scientific Conference of Young Engineers - Kolozsvár, 23-24.03.2017.

[14] N. C. Obinna, T. I. Erdei, Zs. Molnár, G. Husi, „Investigating Configuration Space Singularities of KUKA KR5,'International Mechatronical Student micro-Conference IMS $\mu C^{\prime} 20$ 